\title{
Experimental analysis of biofuel as an alternative fuel for diesel engines Edwin Geo
}

\author{
Varuvel $^{\mathrm{a}, *}$, Nadia Mrad ${ }^{\mathrm{a}}$, Mohand Tazerout ${ }^{\mathrm{a}}$, Fethi Aloui ${ }^{\mathrm{b}}$

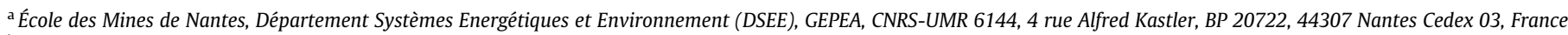 \\ ${ }^{\mathrm{b}}$ Université de Valenciennes et du Hainaut-Cambrésis ENSIAME, Lab. TEMPO - EA 4542, Valenciennes, France
}

\begin{abstract}
The growth of energy demand and limited fossil fuel resources lead to renewable energy development such as vegetable oils and animal fats or their derivatives. In the present work, the valuation of waste fish fat by the pyrolysis technique with the presence of catalyst to produce biofuel for diesel engines. As a result, fuel undergoes good combustion and hence there is a significant improvement in performance and reduction in emissions. The brake thermal efficiency of neat biofuel is $32.4 \%$ at $80 \%$ load which is very high compared to neat diesel (29.98\%). The combustion duration and ignition delay are decreased with neat biofuel due to high oxygen content and high cetane number of biofuel. The main problem with the use of neat biofuel in diesel engine is high $\mathrm{NO}_{x}$ emissions at all loads. Addition of diesel with biofuel reduces the $\mathrm{NO}_{x}$ emissions significantly from $917 \mathrm{ppm}$ to $889 \mathrm{ppm}$ at $80 \%$ load with an optimum blend of B80D20. There is a slight decrease in brake thermal efficiency and increase in particulate emission with this blend. The overall results show that by adding small quantity of diesel with biofuel decreases the $\mathrm{NO}_{x}$ emissions significantly and approaches the performance of neat biofuel.
\end{abstract}

\section{Introduction}

The diesel engine is a major tool in the day-to-day life of modern society. It powers much of our land and sea transport, provides electrical power, used for farming, construction and industrial activities. The fossil fuel scarcity and pollutant emissions from diesel engines have become two important problems of world today. One method to overcome the crisis is to find suitable substitute for the petroleum based fuels [1-3]. Biofuels have been gaining popularity recently as an alternative fuel for diesel engines [4-6]. Biofuels are derived from biomass, and are renewable either through agricultural processes (i.e. growing corn for ethanol) or biological waste generation (i.e. animal waste products). Biofuels can be used in any diesel engine, usually without any modifications. It boasts a reduction in toxic emissions (except $\mathrm{NO}_{x}$ emissions) compared to diesel fuel [7-10].

An increase in world population as well as industrialization, massive amounts of waste material is thrown away from the industries. These waste heaps and streams currently lie there rotting away or dumped as landfill. $\mathrm{CO}_{2}$ trapped in waste is released into the atmosphere during the decaying process $[11,12]$. These problems can be solved by converting these wastes to energy. Waste to Energy (WTE) covers a wide variety of technologies and a process involving the heat treatment of waste (e.g. direct

\footnotetext{
* Corresponding author. Tel.: +33 02518582 81; fax: +33 0251858299 .

E-mail addresses: Varuvel.edwin-geo@mines-nantes.fr, ve_geo@yahoo.com (E.G. Varuvel).
}

combustion (incineration), pyrolysis and gasification) is the best option for the treatment of wastes [13-15]. These strategies promote a comprehensive approach in minimizing the production of waste, recycling, reuse and final disposal of residual waste. The overall objective is to prevent waste, increase the value recovery of resource as biofuel and minimize the amount of waste going for final disposal, especially to landfill. Gasses emitted from the energy generation units can be cleaned without any environmental impact.

The main scope of the present study is to evaluate the performance, emission and combustion characteristics of biofuel and addition of diesel with biofuel in a diesel engine. Biofuel can be used as a neat fuel for diesel engine since their properties are similar to diesel fuel. Many researchers are revealed that the emissions from biofuel fuelled diesel engine give lesser $\mathrm{CO}, \mathrm{HC}, \mathrm{PM}$ and higher $\mathrm{NO}_{x}$. There are different techniques such as blending; water injection and EGR can be used to reduce $\mathrm{NO}_{x}$ emissions in diesel engines [16-18].

\section{Biofuel conversion process}

The fisheries sector plays a vital role in the food supply for the world and in maintaining living hoods in coastal areas. According to Food and Agriculture Organization (FAO), the global total production of fish has continued to increase up to 144.6 million tonnes in 2009 . However, about $54 \%$ of the production is transformed into waste i.e. offal, bones, skin/scales, etc. The fish scales/skin which is a separate by-product is sold for the production of gelatin and 
other valuable products. The other wastes includes heads, bones, tail, etc. which go to make the fish oil. These wastes contain 54\% water, $4 \%$ solid and $42 \%$ fish oil ( $15 \%$ of total mass). The conversion of these wastes gives the solution for fossil fuel scarcity and environmental problems.

The feedstock (waste fish fat-WFF) used in this work was obtained from SIRH group specialized in vegetable, animal and marine oils located in north of France. This waste is the residue of marine oil treatment which is brown in color and was used without any special purification treatment. The typical fatty acid composition has been analyzed by gas chromatography analysis (GC/FID). The saturated acids C14:0, C16:0 and C18:0 were identified. The major fatty acids were unsaturated acids $\mathrm{C} 18: 1$ and $\mathrm{C} 18: 2$ responsible for $45.6 \%$ and $20.6 \%$ respectively of the total composition.

The pyrolysis process, also known as thermal cracking is based on thermo-chemical decomposition of matter in the absence of oxidants $[19,20]$. The products of this decomposition are: a mixture of gases $\left(\mathrm{CO}_{2}, \mathrm{CO}, \mathrm{H}_{2}, \mathrm{CH}_{4}\right.$, etc.), heavy hydrocarbons (gas condensable pyrolysis oil) and coke (carbon fixed and inert residual). The proportions of these products depend on process parameters, namely temperature, heating rate, the residence time of the raw material in the reactor, pressure and the raw material. Also, researchers have focused on the analysis of physicochemical properties of liquid obtained at the end of the process. Indeed, Wiggers et al. [21] studied the pyrolysis of waste fish oil. According to their results, it appears that the liquid product obtained after the process has a high acid index, which is about $131.1 \mathrm{mg}_{\mathrm{Kон}} / \mathrm{g}$, whereas this value should be very low, so it is very difficult to be used as fuel for diesel engines. Hence, the biofuel should be with high quality and has very low acid index. One way to ensure that this is to improve the quality of biofuel produced either at source prior to full production or by upgrading the product. One of the best upgrading options for improving biofuel quality is the addition of catalysts in the pyrolysis process.

In the present work, the catalytic cracking of waste fish fat (WFF) was carried out at temperatures ranging from 350 to $480{ }^{\circ} \mathrm{C}$ with a slow heating rate of $2-3^{\circ} \mathrm{C} / \mathrm{min}$ using a $5 \mathrm{~kW}$ capacity laboratory scale reactor, which is shown in Fig. 1 . The fat was introduced in the reactor and heated by an external electric resistance. The catalyst was placed just above the fat on a bed with small holes. When the temperature inside the reactor reaches $350^{\circ} \mathrm{C}$, the reaction starts. The generated vapor was passed directly over the catalyst surface, before leaving through the top of the reactor. Then it enters in a water-cooled, counter flow, heat ex-change which was kept at $10-15^{\circ} \mathrm{C}$. As a result, three fractions of liquids were collected in the flask: the first is the pyrolysis water, and the second liquid fraction recovered until the temperature reaches $400{ }^{\circ} \mathrm{C}$. The last fraction is the bio-oil recovered from
400 to $480^{\circ} \mathrm{C}$. After acidity analysis, it is found that the second fraction is so acidic (acid value equal to $20 \mathrm{mg}_{\mathrm{KOH}} / \mathrm{g}$ ) compared to the third one (acid value equal to $0.8 \mathrm{mg}_{\mathrm{KoH}} / \mathrm{g}$ ). For this, the main interest is focused on third fraction which is called biofuel. The yield ( $\mathrm{kg}$ bio-fuel $/ \mathrm{kg}$ waste fat) of the liquid products from catalytic cracking process is $72 \%$. The properties of biofuel and diesel are given in Table 1.

\section{Materials and methods}

A single cylinder, four-stroke, air cooled, direct injection, constant speed, diesel engine developing power output of $4.5 \mathrm{~kW}$ was used for this work. Test engine specifications are given in Table 2. The engine was mounted on a fixed table and coupled with an eddy current dynamometer that converts mechanical energy generated by the engine power directly to the net work. Two systems were installed to manage the control and acquisition of measured signals. First system controls the engine-dynamometer and also controls the acquisition of low-frequency measurements (torque, engine speed, pressure and temperature in the collectors). Second system measures high-frequency signal, which mainly concern the cylinder pressure, fuel injection pressure and also the angular position of the crankshaft. The pressure in the cylinder was measured at a frequency of $90 \mathrm{kHz}$ using a piezoelectric pressure sensor, water cooled, type AVL QH32D. The injection pressure was measured by a piezoelectric pressure transducer, type AVL QH33D, located in between the injection pump and the fuel injector. The angular position of the crankshaft was measured by an encoder, type AVL 364C, placed on the flywheel.

The flow of intake air was measured by a differential pressure transmitter; type LPX 5481. For temperature measurements, the test engine was equipped with a series of thermocouples type K. Ambient temperature was measured by an active transmitter for humidity and temperature, type HD 2012 TC/150. The fuel flow was measured using a Coriolis mass flowmeter. For measuring emissions, a bay of analysis (crystal COSMA 500) placed on the line of engine exhaust gas was used to analyze the main pollutant gases. Emissions of hydrocarbons (HC) were measured by FID flame ionization using a heated hydrocarbon analyzer (model GRAPHITE $52 \mathrm{M}$ ), emissions of nitric oxide (NO) and nitrogen oxides $\left(\mathrm{NO}_{x}\right)$ were measured via a chemiluminescence nitrogen oxide analyzer TOPAZE $32 \mathrm{M}$. Emissions of carbon monoxide (CO), carbon dioxide $\left(\mathrm{CO}_{2}\right)$ and oxygen $\left(\mathrm{O}_{2}\right)$ were measured by absorption of infrared radiation using a $2 \mathrm{M}$ MIR analyzer. Particulate emissions were measured using a dust analyzer in real time (TEOM model 1105), for measurement and continuous weighing of the mass

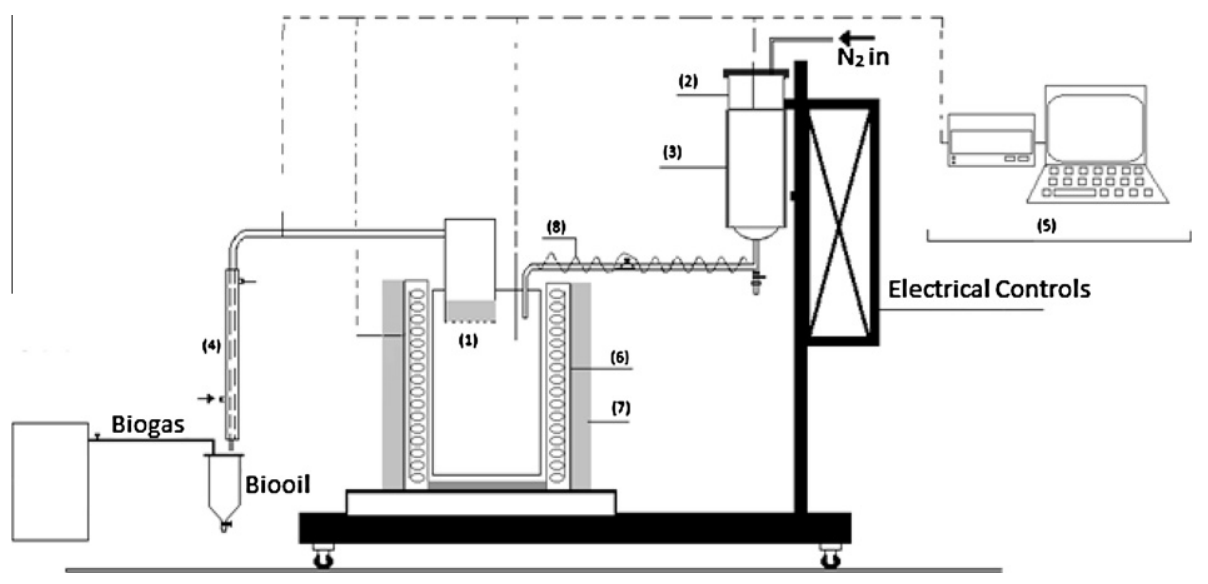


system. (7) Thermal insulation. (8) Electrical resistance. 
Table 1

Properties of biofuel and diesel.

\begin{tabular}{llll}
\hline Properties & Unit & Biofuel & Diesel fuel \\
\hline Flash point & ${ }^{\circ} \mathrm{C}$ & 57 & 56 \\
Acidity & $\mathrm{mg}_{\mathrm{KOH}} / \mathrm{g}$ & 0.8 & - \\
$\mathrm{HHV}$ & $\mathrm{MJ} / \mathrm{kg}$ & 45.10 & 45.71 \\
LHV & $\mathrm{MJ} / \mathrm{kg}$ & 42.74 & 43.36 \\
Dynamic viscosity at $20{ }^{\circ} \mathrm{C}$ & $\mathrm{Ns} / \mathrm{m}^{2}$ & 2.32 & 2.52 \\
Density at $20{ }^{\circ} \mathrm{C}$ & $\mathrm{kg} / \mathrm{m}^{3}$ & 825 & 830 \\
Kinematic viscosity at $20{ }^{\circ} \mathrm{C}$ & $\mathrm{mm} / \mathrm{s}$ & 1.7 & 2 \\
Auto ignition temperature & ${ }^{\circ} \mathrm{C}$ & 230 & 220 \\
Cetane number & & 57 & 52 \\
Cloud point & ${ }^{\circ} \mathrm{C}$ & 9 & - \\
Pour point & ${ }^{\circ} \mathrm{C}$ & -5 & - \\
Cold filter plugging point & ${ }^{\circ} \mathrm{C}$ & 14 & - \\
\hline
\end{tabular}

Table 2

Specifications of Test Engine.

\begin{tabular}{ll}
\hline Make & Lister petter \\
\hline No of cylinders & One \\
Type of cooling & Air cooled \\
Bore $\times$ Stroke & $95.5 \times 88.94 \mathrm{~mm}$ \\
Length of connecting rod & $165.3 \mathrm{~mm}$ \\
Displacement & $630 \mathrm{~cm}^{3}$ \\
Fuel injection timing & $20{ }^{\circ} \mathrm{bDC}$ \\
Fuel injection pressure & $250 \mathrm{bar}$ \\
Compression ratio & $18: 1$ \\
Rated power & $4.5 \mathrm{~kW} @ 1500 \mathrm{rpm}$
\end{tabular}

concentration of particulate exhaust. The schematic of test engine setup is shown in Fig. 2.

\section{Results and discussion}

Biofuel from waste fish fat offers the advantage of freely mixing with diesel and these blends can be used in the existing diesel engine without any modifications. Initially, the biofuel and diesel were taken in separate container then it was measured for the different proportions by volume basis. The measured quantity of biofuel and diesel were mixed together in a container. Mixing of the products occurs as the fuel (blend) is agitated through the blending of each fuel for $15 \mathrm{~min}$. For the $24 \mathrm{~h}$ observation of blend for any phase separation, the blend was used as a fuel for diesel engine. Experiments were conducted with neat biofuel (B100), diesel and different blends of diesel and biofuel (B80D20 and B60D40).

\subsection{Performance parameters}

\subsubsection{Brake thermal efficiency}

Fig. 3 shows the variation of brake thermal efficiency with brake power for biofuel, diesel and diesel addition with biofuel. At $80 \%$ load neat biofuel (B100) results in maximum brake thermal efficiency of $32.4 \%$, whereas the neat diesel leads to a brake thermal efficiency of $29.98 \%$. The maximum brake thermal efficiency with biofuel is due to high oxygen content and high cetane number of biofuel. There is a slight reduction in brake thermal efficiency when the diesel is added with biofuel. The blend containing $80 \%$ of biofuel shows the brake thermal efficiency of $31.8 \%$ and $60 \%$ biofuel has a brake thermal efficiency of $31.5 \%$ at $80 \%$ load. There is not much difference in brake thermal efficiency between B80D20 and B60D40 blend and the difference is only about 0.3\%. Also, the difference in brake thermal efficiency between biofuel and B80D20, B60D40 is 0.6\% and 0.9\%. This slight change in brake thermal efficiency is due to decrease in oxygen content in the blend. The brake thermal efficiency decreases marginally with all fuels at full load. It is about $30.8 \%$ for biofuel, $28.69 \%$ for diesel, $30.14 \%$ for B80D20 and $30.02 \%$ for B60D40. The quantity of fuel injected at full load is high, but the ignition delay at full load is shorter which shows that the fuel prepared during ignition delay is very low compared to total fuel injected. Hence, more amount of fuel is burned after premixed combustion which reduces the brake thermal efficiency at full load. Normally in $\mathrm{CI}$ engines, the premixed combustion directly reflects the brake thermal efficiency.

\subsubsection{Exhaust gas temperature}

The variation of exhaust gas temperature with brake power for various fuels is shown in Fig. 4. The exhaust gas temperature increases with the increase in load. It is lower with biofuel compared to all fuels which has a value of $422^{\circ} \mathrm{C}$ at full load. The addition of diesel with biofuel increases the exhaust gas temperature slightly. The exhaust gas temperature for B80D20 and B60D40 blend is $430{ }^{\circ} \mathrm{C}$ and $432{ }^{\circ} \mathrm{C}$ respectively at full load. It is almost same with both the blends. It is further increased to the maximum of $495^{\circ} \mathrm{C}$ with neat diesel. From brake thermal efficiency, it is observed that the amount of fuel injected is more with diesel and blends. The amount of fuel prepared during premixed combustion is reduced with diesel and blends. Hence, amount of fuel takes part during the initial phase of combustion is very less. Due to that more quantity of fuel is burned in later part of combustion which leads to higher exhaust gas temperature with diesel and blends. It is low with blends compared neat diesel.

\subsection{Emission parameters}

\subsubsection{Oxides of nitrogen emissions $\left(\mathrm{NO}_{x}\right)$}

The variation of $\mathrm{NO}_{x}$ emissions with brake power for biofuel, diesel and different blends is presented in Fig. 5. $\mathrm{NO}_{x}$ emissions increase from $20 \%$ load to $80 \%$ load and there is a drop at full load with all fuels. $\mathrm{NO}_{x}$ emissions for the neat biofuel operation is $857 \mathrm{ppm}$ at full load which is maximum compared other test fuels. The increase in $\mathrm{NO}_{x}$ with neat biofuel operation is due to the higher intensity of premixed combustion. The higher premixed combustion is due to higher centane number of biofuel which initiates the combustion early. Also, the fuel is burned quickly due to its higher oxygen content. The main reason of mixing diesel with biofuel is to find the trade-off between $\mathrm{NO}_{x}$ and particulate emission with minimum use of diesel. $\mathrm{NO}_{x}$ emissions decrease as the amount of diesel in the blend goes up. $\mathrm{NO}_{x}$ emissions are $841 \mathrm{ppm}$ with B80D20 blend and 826 ppm with B60D40 blend at full load. The decrease in $\mathrm{NO}_{x}$ is due to the poor mixing of fuel and air which leads to decrease the premixed combustion. It is further reduced to the minimum of $780 \mathrm{ppm}$ with neat diesel. At $80 \%$ load, the $\mathrm{NO}_{x}$ emissions are very high with all fuels. At $80 \%$ load, the $\mathrm{NO}_{x}$ emissions with biofuel, diesel, B80D20 and B60D40 are $971 \mathrm{ppm}, 852 \mathrm{ppm}, 889 \mathrm{ppm}$ and $883 \mathrm{ppm}$ respectively. There is no marginal difference in $\mathrm{NO}_{x}$ emissions between B80D20 and B60D40 at $80 \%$ load.

\subsubsection{Unburned hydrocarbon emissions (UHC)}

Fig. 6 shows the variation of unburned hydrocarbons with brake power for biofuel, diesel and their blends. It is seen that neat biofuel operation emits lower UHC compared to all other fuels. The amount of oxygen participates during combustion will increase the oxidation process. There is more oxygen chemically bounded with oxygen in biofuel which is an additional source of oxygen other than oxygen present in the intake air. This oxygen helps for the formation of air fuel mixture and it takes part in complete combustion. The intensity of UHC in the exhaust gas increase as the quantity of diesel increases in the blend is due to less quantity of oxygen in the blend. This can be verified by the formation of particulate emissions. UHC emissions for biofuel, diesel, B80D20 and 

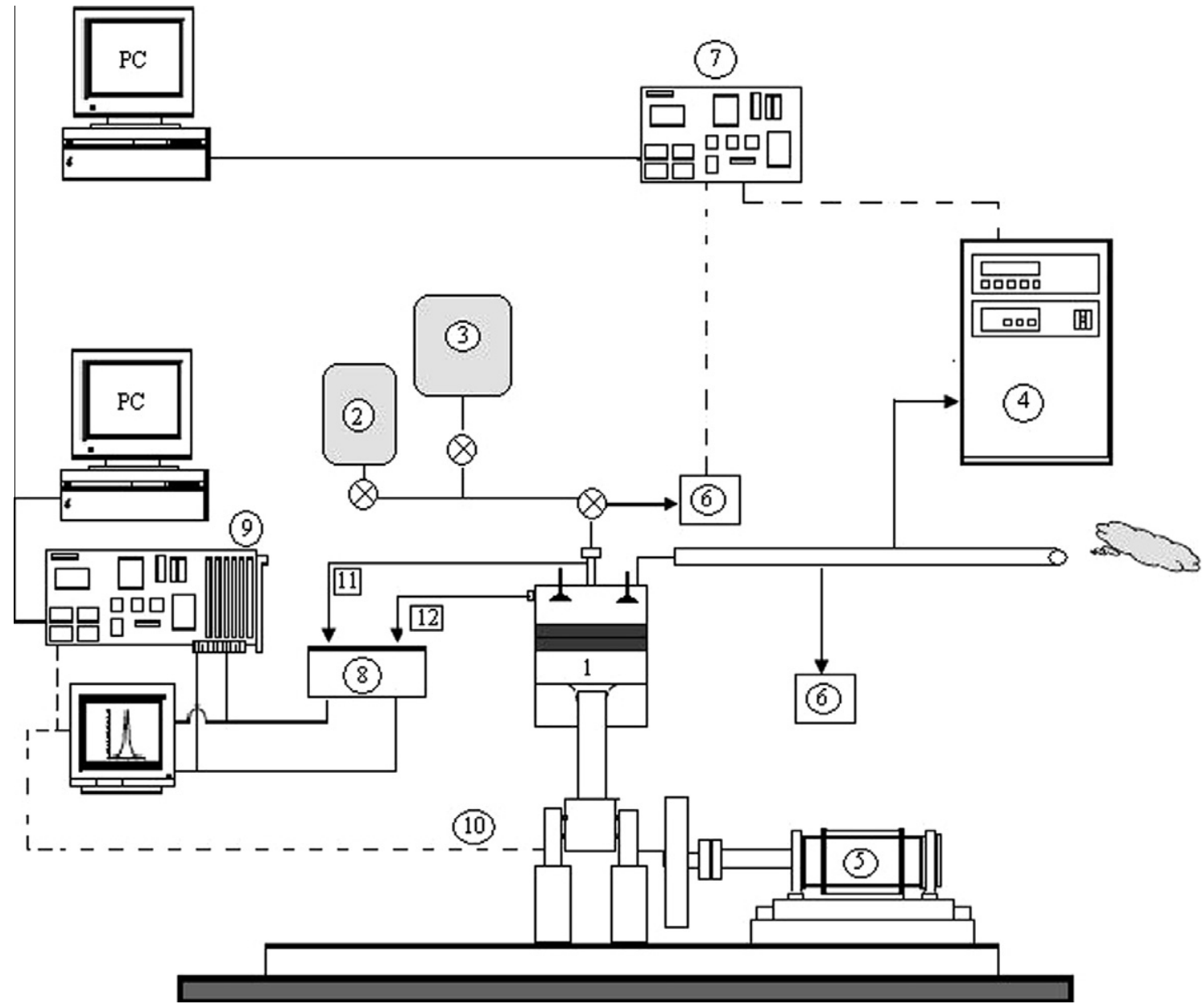

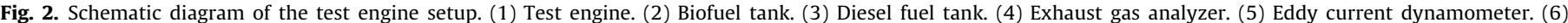

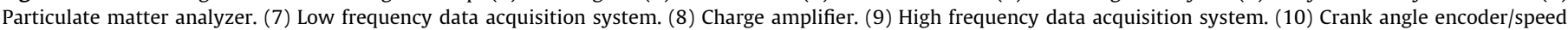
sensor. (11) Injection pressure signal. (12) Cylinder pressure signal.



Fig. 3. Variation of brake thermal efficiency with brake power.

B60D40 at full load are 502 ppm, 575 ppm, 518 ppm and 520 ppm respectively. It is very clear that the UHC are very high for neat diesel compared to all test fuels. Also, there is not much difference in UHC emissions between B80D20 and B60D40 blend.

\subsubsection{Carbon monoxide emission (CO)}

The variation in $\mathrm{CO}$ emission with brake power for different test fuels is given in Fig. 7. The neat biofuel gives slightly lower CO

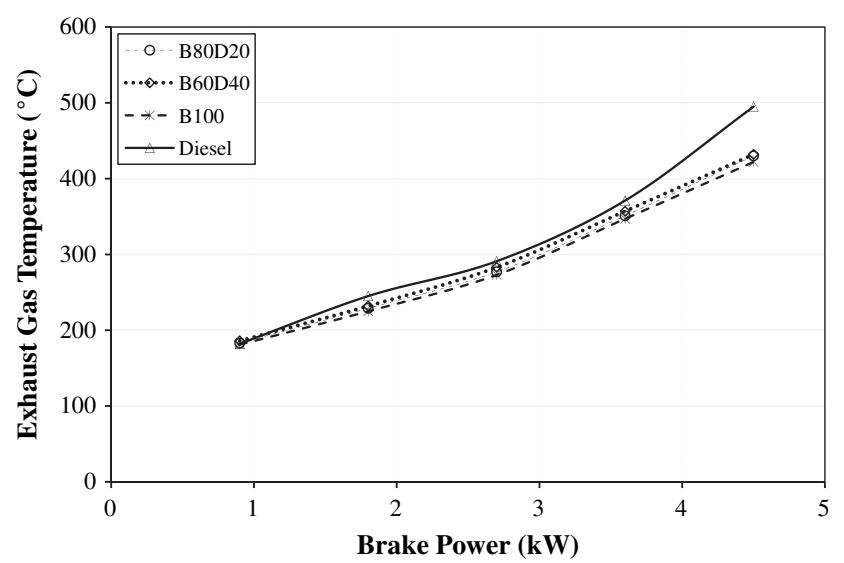

Fig. 4. Variation of exhaust gas temperature with brake power

emission compared to diesel and other blends. This may be due to higher oxygen and combustion temperature enhances the oxidation of $\mathrm{CO}$ to $\mathrm{CO}_{2}$. $\mathrm{CO}$ emission increases with the blends as compared to neat biofuel. These trends indicate that the combustion efficiency decreases with the blend of diesel with biofuel. The combustion rate is reduced and hence the carbon monoxide emission increases with the addition of diesel to biofuel. It is further 


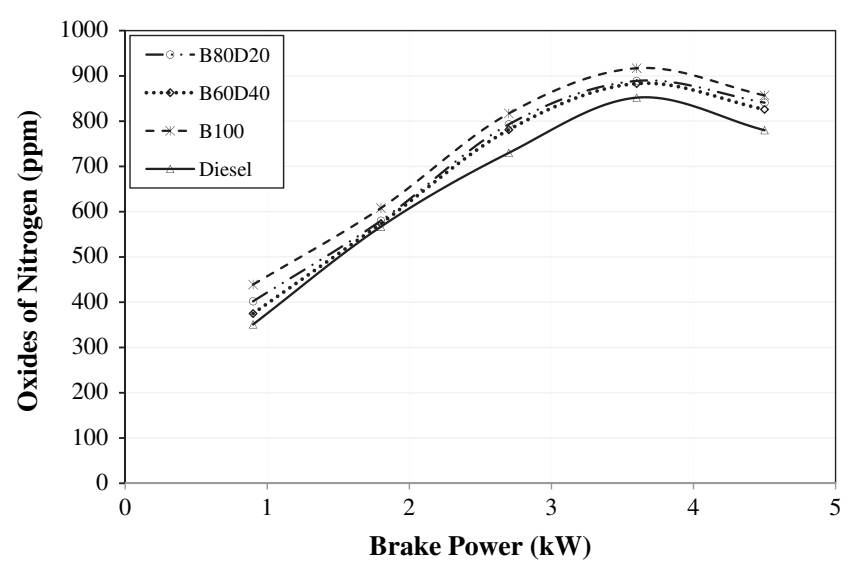

Fig. 5. Variation of oxides of nitrogen with brake power.

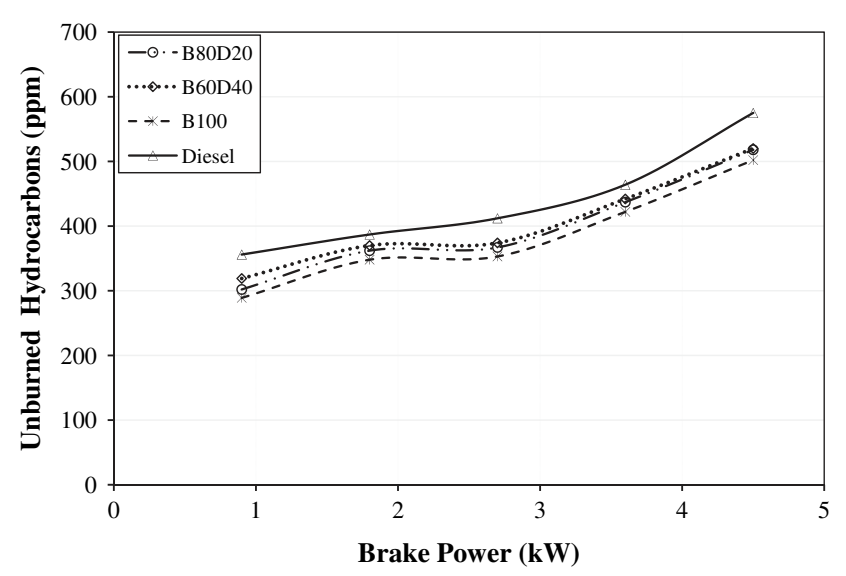

Fig. 6. Variation of unburned hydrocarbons with brake power.

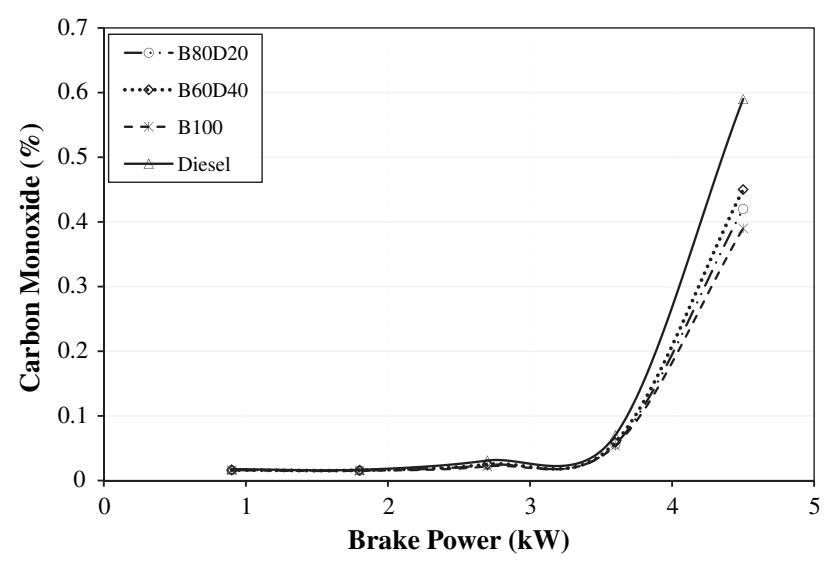

Fig. 7. Variation of carbon monoxide with brake power.

increased with neat diesel over other test fuels. The increase in the quantity of diesel in the blend decreases the engine performance as well as increases the $\mathrm{CO}$ emission. The percentage of $\mathrm{CO}$ emission with neat biofuel, neat diesel, B80D20 and B60D40 is $0.39 \%$, $0.59 \%, 0.42 \%$ and $0.45 \%$ respectively at full load. The difference in $\mathrm{CO}$ emission between two blends is less which is about $0.03 \%$.

\subsubsection{Carbon dioxide emission $\left(\mathrm{CO}_{2}\right)$}

The variation of $\mathrm{CO}_{2}$ emission with brake power for various fuels is shown in Fig. 8. The $\mathrm{CO}_{2}$ gas is the main source for global warming and ozone layer depletion. The main disadvantage of biofuel as fuel for diesel engine is higher $\mathrm{CO}_{2}$ emission. It has been understood that high oxygen bounded biofuel contributes significantly better combustion than any other fuels. The intensity of combustion directly reflects $\mathrm{CO}_{2}$ formation. The $\mathrm{CO}_{2}$ emission with neat biofuel operation is $9.74 \%$ at full load which is very high compared to all other fuels. This is due to oxygen bounded in the biofuel contributes better mixing rate and leads to better oxidation of fuel which results more $\mathrm{CO}$ is converted to $\mathrm{CO}_{2}$. The $\mathrm{CO}_{2}$ reduces with the addition of diesel with biofuel. It is $9.5 \%$ for B80D20, 9.42\% for B60D40 and 9.15\% for diesel which shows that diesel emits less $\mathrm{CO}_{2}$ over other test fuels.

\subsubsection{Oxygen $\left(\mathrm{O}_{2}\right)$}

Fig. 9 depicts the variation of oxygen percentage with brake power for biofuel, diesel and different biofuel/diesel blends. The percentage of oxygen present in the biofuel is higher. This oxygen as well as oxygen from intake air take part in the combustion then excess oxygen is exhausted. The $\mathrm{O}_{2}$ percentage in the exhaust gas for the neat biofuel operation is very low (8.5\%) which indicates that more amount of oxygen participates in the combustion process to release heat energy. There is a slight increase in oxygen percentage with biofuel and diesel blends. It is about $8.85 \%$ for B80D20 and 8.93\% for B60D40 which shows that poor combustion results in higher oxygen. It is very high with neat diesel which is about $9.45 \%$. The increase of oxygen with diesel fuel operation is due to inferior combustion compared to neat biofuel.

\subsubsection{Particulate matter (PM)}

Fig. 10 shows the variation of particulate emissions with brake power for biofuel, diesel and different blends of biofuel and diesel. The PM emissions for neat biofuel are very low compared to all other test fuels. The presences of oxygen in the fuel and intake air improve the air fuel mixing rates which help to prepare more quantity of fuel for premixed combustion. The high cetane number of biofuel starts the combustion early. Also, the combustion duration is very less with biofuel. All the above mentioned reasons will lead to reduce the PM in the exhaust. There is a slight increase in PM emission with biofuel/diesel blends. The increased combustion duration due to longer ignition delay, increases the PM. Also, excess oxygen is needed to enhance or convert carbon particle to $\mathrm{CO}_{2}$. It is very high with neat diesel. The PM emissions for biofuel, diesel, B80D20 and B60D40 at full load are $0.028 \mathrm{~g} / \mathrm{h}, 0.03 \mathrm{~g} / \mathrm{h}, 0.0288 \mathrm{~g} /$ $\mathrm{h}$ and $0.029 \mathrm{~g} / \mathrm{h}$ respectively. There is not much difference of PM between B80D20 and B60D40 and it is only about $0.0002 \mathrm{~g} / \mathrm{h}$.



Fig. 8. Variation of carbon dioxide with brake power. 


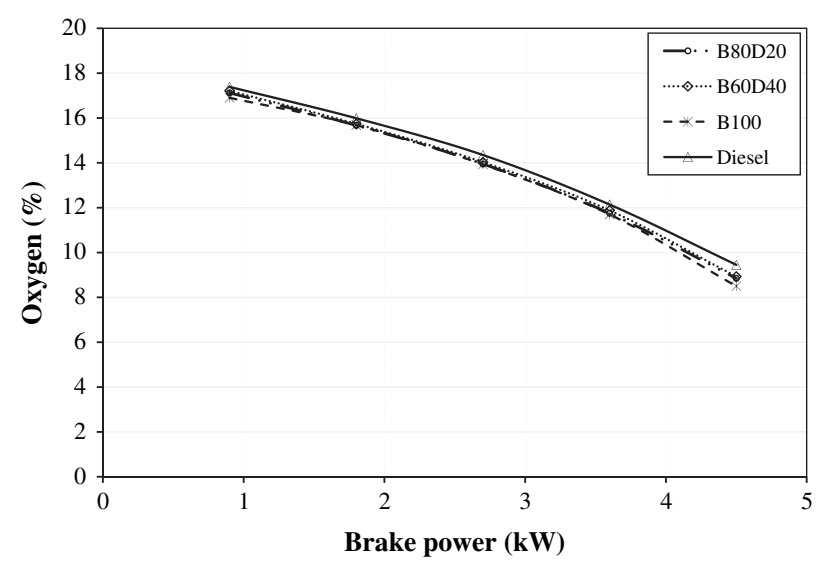

Fig. 9. Variation of oxygen percentage with brake power.

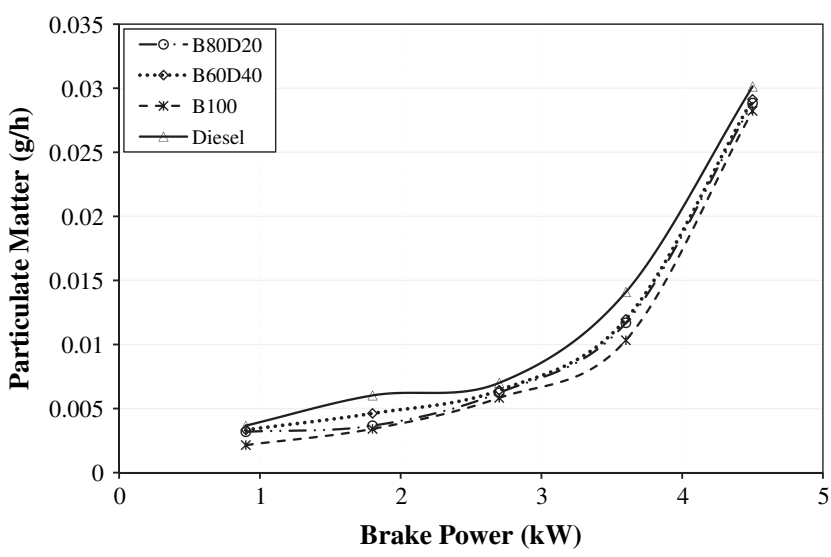

Fig. 10. Variation of particulate matter with brake power.

\subsection{Combustion parameters}

\subsubsection{Cylinder pressure}

Fig. 11 shows the variation of cylinder peak pressure with brake power. The cylinder peak pressure with neat biofuel is very high compared to all other test fuels. The chemically bound oxygen in biofuel is the reason for the increased cylinder pressure. The fuel inside the combustion chamber reacts with oxygen and releases energy which is used to increase the cylinder pressure. The cylinder pressure decreases if diesel concentration in the blend

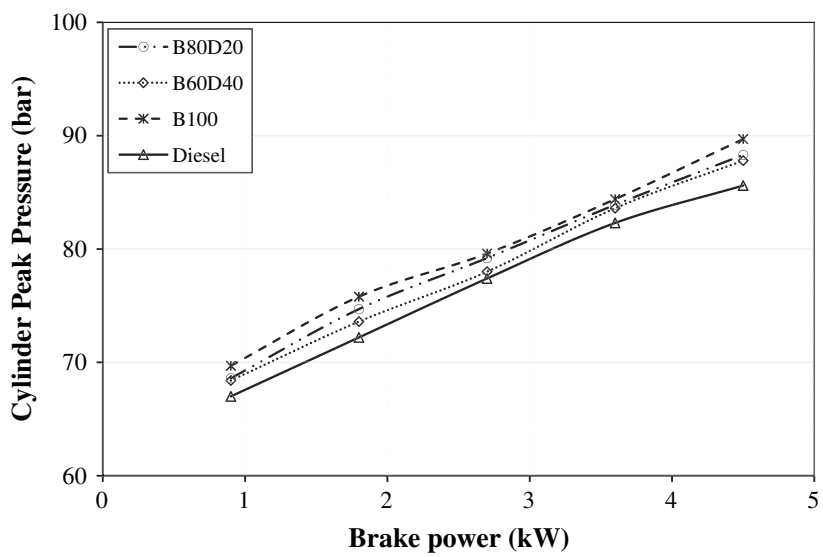

Fig. 11. Variation of cylinder peak pressure with brake power. increases. It is 89.7 bar with neat biofuel, 85.6 bar with neat diesel, 88.3 bar with B80D20 and 87.8 bar with B60D40. This decrease of cylinder pressure with neat diesel and different blends is due to lag in oxygen concentration during combustion reduces the rate of combustion.

The variation of cylinder pressure at full load with crank angle is shown in Fig. 12. It clearly shows that the occurrence of maximum pressure. It is observed that the maximum cylinder pressure is occurred at $4.3^{\circ} \mathrm{CA}$ after TDC with neat biofuel, $6.1^{\circ} \mathrm{CA}$ after TDC with neat diesel, $4.7^{\circ} \mathrm{CA}$ after TDC with B80D20 and $5.5^{\circ} \mathrm{CA}$ after TDC with B60D40. The shift of occurrence of peak pressure shows the direct reflection on heat release. The maximum peak pressure occurred very early with biofuel and it is late with diesel and various biofuel/diesel blends. This shows that the heat energy is released very late due to that the brake thermal efficiency is reduced and exhaust gas temperature is increased.

\subsubsection{Rate of heat release}

The variation of heat release rate with crank angle at full load is shown in Fig. 13. The premixed combustion with biofuel is very sharp and the diffusion combustion is low which reflect on the rate of combustion. Even though the ignition delay of neat biofuel is less, the premixed combustion rate is quite high. This indicates that most of the fuel injected during the delay period is prepared for ignition and it is participated during premixed combustion process which is reflected on the formation of $\mathrm{NO}_{x}$. Fig. 13 also shows that, neat diesel displays lower premixed peak and then it is increased by blending with biofuel. Also, the intensity of diffusion phase of combustion showed by the area under the second peak in the heat release diagram is higher for neat diesel followed by B60D40 and then B80D20. At the time of ignition, the amount of fuel-air mixture is prepared with blends and diesel for combustion is less which results less fuel burned during premixed combustion and more fuel burned at diffusion combustion. The occurrence of maximum premixed heat release is advanced by about $1.2^{\circ} \mathrm{CA}$ with biofuel than diesel. The effective expansion will take place when the premixed combustion is advanced. The occurrence of maximum premixed combustion is $8.3^{\circ} \mathrm{CA}$ before TDC with biofuel, $8{ }^{\circ} \mathrm{CA}$ before TDC with B80D20, $7.8^{\circ} \mathrm{CA}$ before TDC with B60D40 and $7.1^{\circ} \mathrm{CA}$ before TDC with diesel.

\subsubsection{Ignition delay}

Fig. 14 shows the variation of ignition delay with brake power for biofuel, diesel and different blends of biofuel and diesel. Ignition delay comprising of physical and chemical delay. During physical delay, the injected fuel vaporizes and fuel vapor mixes with air. The chemical delay is the pre-combustion of fuel and air mixture

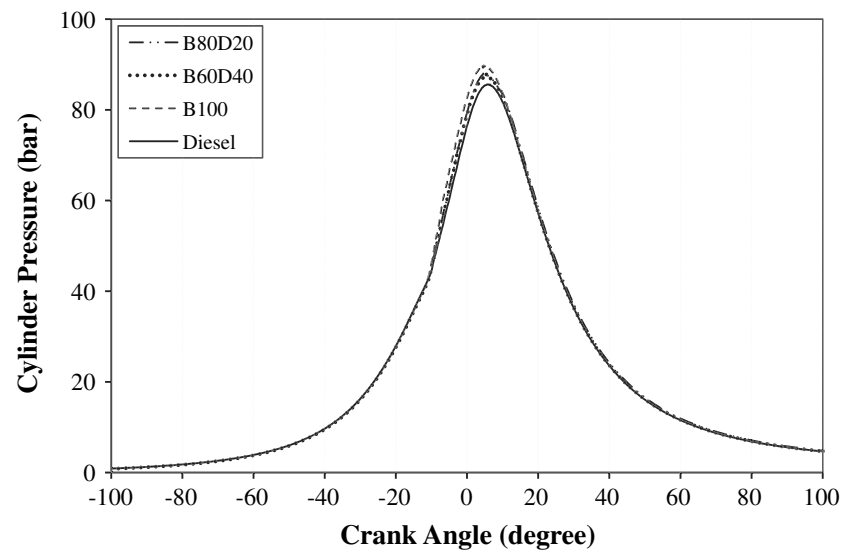

Fig. 12. Variation of cylinder pressure with crank angle at maximum load. 


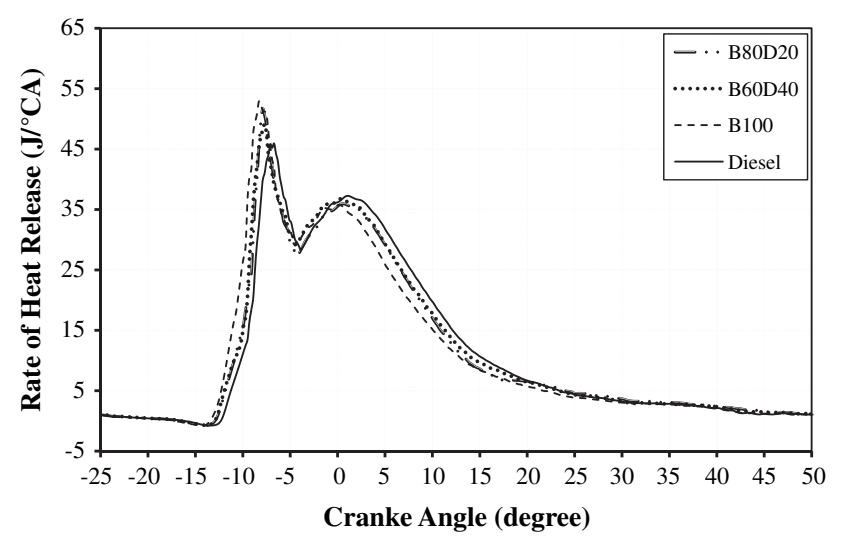

Fig. 13. Variation of heat release rate with crank angle at maximum load.

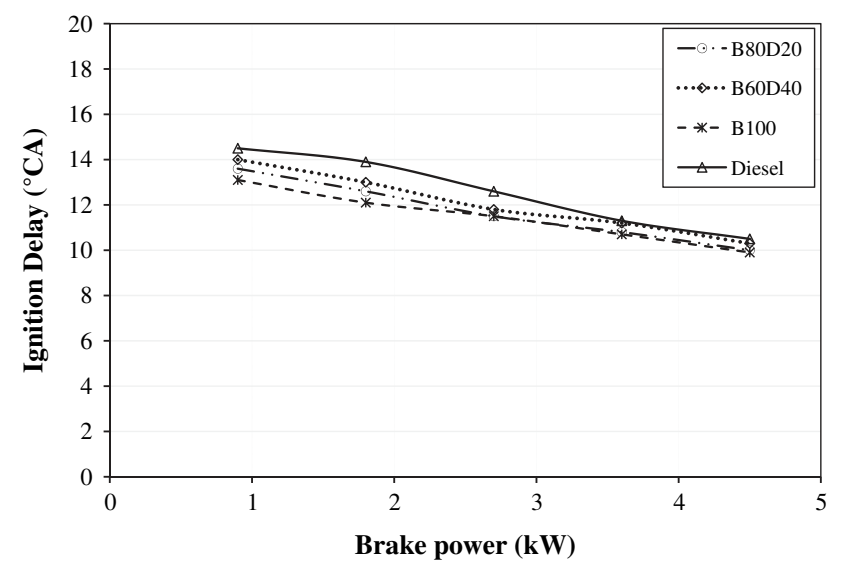

Fig. 14. Variation of ignition delay with brake power.

which leads to auto ignition. Ignition delay is shorter with biofuel compared to diesel and other blends. This is mainly due to the shortening of the physical delay and also the high cetane number of biofuel. The oxygen present in the fuel increases the air fuel mixing rate which reduces the physical delay and higher cetane number of fuel starts the ignition earlier. The ignition delay increases with the increase of diesel concentration in the blend. This is mainly due to less oxygen present in the fuel. The ignition delay is $9.9^{\circ} \mathrm{CA}$ with biofuel, $10.5^{\circ} \mathrm{CA}$ with diesel, $10^{\circ} \mathrm{CA}$ with B80D20 and $10.3^{\circ} \mathrm{CA}$ with B60D40 at full load.

\subsubsection{Combustion duration}

The variation of combustion duration with brake power for biofuel, diesel and blends is shown in Fig. 15. The combustion duration is reduced with biofuel compared to all other test fuels. For biofuel/diesel blends, it increases with increase in percentage of diesel in the blend. Diesel and biofuel/diesel blends require more quantity of fuel to maintain the same power output. Due to that more amount of fuel is injected with diesel and blends lead to longer combustion duration. Longer combustion duration indicates that too much fuel is injected as the cylinder cools down during the expansion stroke, potentially causing incomplete combustion. The combustion duration for biofuel, diesel, B82D20 and B60D40 at full load is $41.2^{\circ} \mathrm{CA}, 44.7^{\circ} \mathrm{CA}, 12^{\circ} \mathrm{CA}$ and $42.5^{\circ} \mathrm{CA}$ respectively.

\section{Analysis of uncertainty}

In measuring any quantity, the results will always differ from the true value even with careful experimentation. This error in



Fig. 15. Variation of combustion duration with brake power.

Table 3

Sensitivity of Instruments used.

\begin{tabular}{|c|c|c|}
\hline Parameter & Sensor type & Error \\
\hline Torque $\left(T_{m}\right)$ & Effort sensor (FN 3148) & $\pm 0,1$ N.m \\
\hline Engine speed & AVL 364C & \pm 3 RPM \\
\hline Injection timing & AVL 364C & $\pm 0.05^{\circ} \mathrm{CA}$ \\
\hline Intake air flow rate & $\begin{array}{l}\text { Differential pressure transmitter } \\
\text { (LPX5841) }\end{array}$ & $\begin{array}{l} \pm 1 \% \text { of measured } \\
\text { value }\end{array}$ \\
\hline Fuel flow rate & $\begin{array}{l}\text { Coriolis type mass flowmeter } \\
\text { (RHM015) }\end{array}$ & $\begin{array}{l} \pm 0.5 \% \text { of measured } \\
\text { value }\end{array}$ \\
\hline In cylinder pressure & Piezo-electric (AVL QH32D) & \pm 2 bars \\
\hline Injection pressure & Piezo-electric (AVL QH33D) & \pm 2.5 bars \\
\hline $\begin{array}{l}\text { Intake air } \\
\text { temperature }\end{array}$ & $\begin{array}{l}\text { Differential pressure transmitter } \\
\text { (LPX5841) }\end{array}$ & $\pm 1.6 \mathrm{~K}$ \\
\hline $\begin{array}{l}\text { Fuel injection } \\
\text { temperature }\end{array}$ & K type thermocouple & $\pm 1.6 \mathrm{~K}$ \\
\hline $\begin{array}{l}\text { Exhaust gas } \\
\text { temperature }\end{array}$ & K type thermocouple & $\pm 1.6 \mathrm{~K}$ \\
\hline $\begin{array}{l}\text { Ambient air } \\
\text { temperature }\end{array}$ & HD 2012 TC/150 & $\pm 0.2 \mathrm{~K}$ \\
\hline Relative humidity & HD 2012 TC/150 & $\pm 2 \%$ \\
\hline $\begin{array}{r}\text { Hydrocarbon } \\
\text { emissions }\end{array}$ & FID (GRAPHITE $52 \mathrm{M}$ ) & $\pm 10 \mathrm{ppm}$ \\
\hline $\begin{array}{r}\text { Nitric oxides } \\
\text { emissions }\end{array}$ & TOPAZE $32 \mathrm{M}$ & $\pm 100 \mathrm{ppm}$ \\
\hline $\begin{array}{l}\text { Carbon dioxide } \\
\text { emissions }\end{array}$ & Infra-red detector (MIR $2 \mathrm{M}$ ) & $\pm 0.2 \%$ \\
\hline Non-reacted oxygen & Infra-red detector (MIR $2 \mathrm{M}$ ) & $\pm 0,25 \%$ \\
\hline $\begin{array}{l}\text { Carbon monoxide } \\
\text { emissions }\end{array}$ & Infra-red detector (MIR $2 \mathrm{M}$ ) & $50 \mathrm{ppm}$ \\
\hline $\begin{array}{l}\text { Particulate matter } \\
\text { emissions }\end{array}$ & TEOM 1105 & $\pm 10 \mathrm{ng} / \mathrm{s}$ \\
\hline $\begin{array}{l}\text { Fuel lower heating } \\
\text { value }\end{array}$ & $\begin{array}{l}\text { Isoperibol calorimeter (PARR } \\
\text { 6200CLEF) }\end{array}$ & $\begin{array}{l} \pm 0,25 \% \text { of measured } \\
\text { value }\end{array}$ \\
\hline
\end{tabular}

measurement may be either random or systematic. By adding a correction value, the systematic error can be removed. Random error can only be estimated statistically and cannot be predicted in advance. Its presence can be detected only when the same quantity is measured again and again under the same conditions and with the same care.

The uncertainty was estimated based on Gaussian distribution method with confidence level of $\pm 2 \sigma$ ( $95.45 \%$ of measured data lie within the limits of $\pm 2 \sigma$ of mean). Thus uncertainty is estimated using the following equation.

Uncertainty of any measured parameter $(\Delta X)=2 \sigma i / \bar{X} * 100$

Experiments were conducted to obtain the mean $(\bar{X})$ and standard deviation $(\sigma i)$ of any measured parameter $(X i)$ for 20 readings. From 
the measured parameters, the uncertainty is computed based on Kline and McClintock method [22].

Let $R$ be the computed quantity from $n$ independent measured parameters

$X_{1}, X_{2}, X_{3} \ldots X_{n}$

Thus

$R=R\left(X_{1}, X_{2}, X_{3} \ldots X_{n}\right)$

Let uncertainty limits for the measured parameters be

$X_{1} \pm \Delta X_{1}, X_{2} \pm \Delta X_{2}, X 3 \pm \Delta X_{3}, \ldots, X_{n} \pm \Delta X_{n}$

and the uncertainty limit for the computed value be $R \pm \Delta R$

In order to get the realistic error limits for any computed quantity based on several measured quantities the principle of rootsum-square method is used and the magnitude of the error is given by

$$
\begin{aligned}
\Delta R= & \operatorname{SQRT}\left(\left(\partial R / \partial X_{1} * \Delta X_{1}\right)^{2}+\left(\partial R / \partial X_{2} * \Delta X_{2}\right)^{2}+\ldots\right. \\
& \left.+\left(\partial R / \partial X_{n} * \Delta X_{n}\right)^{2}\right)
\end{aligned}
$$

Using the Eq. (3) the uncertainty for a given operating condition was computed.

The estimated uncertainty values at different operating conditions are

- Brake power:0.4-1.7\%

- Specific fuel consumption:0.5-1.9\%

- Brake thermal efficiency:0.6-1.9\%

The sensitivity of the various instruments used in this experimental study is given in Table 3 .

\section{Conclusions}

The following conclusions are drawn based on this experimental study. In the case of neat biofuel and its blend with diesel the followings are the main observations.

- The brake thermal efficiency is high with neat biofuel and it is reduced slightly with diesel addition. It is decreased from $32.4 \%$ to $31.8 \%$ with the optimum blend of B80D20 at $80 \%$ load.

- Exhaust gas temperature is lower with neat biofuel as compared to diesel due to early combustion. The exhaust temperature increases with increase in quantity of diesel in the biofuel-diesel blend.

- $\mathrm{NO}_{x}$ emissions are very high with neat biofuel compared to diesel due to higher premixed combustion. There is a marginal reduction in $\mathrm{NO}_{x}$ emissions with blends of diesel and biofuel.

- UHC and CO emissions are found to be very low with neat biofuel. Increase in UHC and CO emission is noticed with diesel and biofuel blends.

- Significant reductions in particulate emissions are observed with neat biofuel compared to diesel. This is due to better mixture formation of neat biofuel. There is not much change in PM emissions with biofuel-diesel blends.
- The premixed combustion is increased and diffusion combustion is reduced with neat biofuel which lead to higher $\mathrm{NO}_{x}$ and lower PM emissions. The combustion deteriorates with blending which decreases the premixed combustion.

Finally, it is observed that there is a reduction in $\mathrm{NO}_{x}$ emission with blending of small quantity of diesel with biofuel (B80D20) and not much variation in brake thermal efficiency and other emissions.

\section{References}

[1] No Soo Young. Inedible vegetable oils and their derivatives for alternative diesel fuels in CI engines: A review. Renew Sust Energy Rev 2011;15:131-49.

[2] Lin Lin, Cunshan Zhou, Vittayapadung Saritporn, Xiangqian Shen, Mingdong Dong. Opportunities and challenges for biodiesel fuel. Appl Energy 2011;88: 1020-31.

[3] Demirbas A. Biodiesel: a realistic fuel alternative for diesel engines. London: Springer; 2008.

[4] Agarwal AK. Biofuels (alcohols and biodiesel) applications as fuels for internal combustion engines. Prog Energy Combust Sci 2007;33:233-71.

[5] Senthilkumar M, Remesh A, Nagalingam B. Complete vegetable oil fueled dual fuel compression ignition engine. SAE 2001-28-0067; 2001.

[6] Vollebergh Herman. Environmental externalities and social optimality in biomass markets: waste-to-energy in The Netherlands and biofuels in France. Energy Policy 1997;25:605-21.

[7] Sun Jiafeng, Caton Jerald A, Jacobs Timothy J. Oxides of nitrogen emissions from biodiesel-fuelled diesel engines. Prog Energy Combust Sci 2010;36: 677-95.

[8] Guru Metin, Koca Atilla, Can Ozer, Cınar Can, Sahin Fatih. Biodiesel production from waste chicken fat based sources and evaluation with $\mathrm{Mg}$ based additive in a diesel engine. Renew Energy 2010;35:637-43.

[9] Senthil Kumar M, Kerihuel A, Bellettre J, Tazerout M. Experimental investigations on the use of preheated animal fat as fuel in a compression ignition engine. Renew Energy 2005;30:1443-56.

[10] Behçet Rasim. Performance and emission study of waste anchovy fish biodiesel in a diesel engine. Fuel Process Technol 2011;92:1187-94.

[11] Daskalopoulos E, Badr O, Probert DS. Economic and environmental evaluations of waste treatment and disposal technologies for municipal solid waste. Appl Energy 1997;58:209-55.

[12] Gardner N, Manley BJW, Pearson JM. Gas emissions from landfills and their contributions to global warming. Appl Energy 1993;44:165-74.

[13] Montejo Cristina, Costa Carlos, Ramos Pedro, del Carmen Márquez María. Analysis and comparison of municipal solid waste and reject fraction as fuels for incineration plants. Appl Therm Eng 2011;31:2135-40.

[14] Wisniewski Jr A, Wiggers VR, Simionatto EL, Meier HF, Barros AAC, Madureira LAS. Biofuels from waste fish oil pyrolysis: chemical composition. Fuel 2010;89:563-8.

[15] Morris M, Waldheim L. Energy recovery from solid waste fuels using advanced gasification technology. Waste Manag 1998;18:557-64.

[16] Armasa O, Ballesterosa R, Martosb FJ, Agudelo JR. Characterization of light duty Diesel engine pollutant emissions using water-emulsified fuel. Fuel 2005;84: 1011-8.

[17] Saleh HE. Experimental study on diesel engine nitrogen oxide reduction running with jojoba methyl ester by exhaust gas recirculation. Fuel 2009;88: 1357-64.

[18] Pisupati Sarma V, Bhalla Sumeet. Numerical modeling of $\mathrm{NO}_{x}$ reduction using pyrolysis products from biomass-based materials. Biomass Bioenerg 2008;32:146-54.

[19] Maher KD, Bressler DC. Pyrolysis of triglyceride materials for the production of renewable fuels and chemicals. Bioresour Technol 2007;98:2351-68.

[20] Dandik L, Ayse Aksoy H. Pyrolysis of used sunflower oil in the presence of sodium carbonate by using fractionating pyrolysis reactor. Fuel Process Technol 1998;57:81-92.

[21] Wiggers VR, Wisniewski Jr A, Madureira LAS, Chivanga Barros AA, Meier HF. Biofuels from waste fish oil pyrolysis: Continuous production in a pilot plant. Fuel 2009;88:2135-41.

[22] Kline SJ, McClintock FA. Describing uncertainties in single sample experiments. Mech Eng 1953;3. 